\title{
Metal Accumulation and Functional Traits of Maianthemum bifolium (L.) F. W. Schmidt in Acid Beech Forests Differing with Pollution Level
}

\author{
Karolina Bierza
}

Received: 13 September 2021 / Accepted: 26 January 2022 / Published online: 9 February 2022

(C) The Author(s) 2022

\begin{abstract}
Maianthemum bifolium (L.) F. W. Schmidt is a clonal plant with a wide geographical range throughout Europe and Asia. It is also abundant as an understory plant of acid beech forests in southern Poland. The response strategies of this species to heavy metals and their effects on some functional traits (height, specific leaf area (SLA), leaf dry matter content (LDMC), specific rhizome length (SRL) and rhizomes dry matter content (RDMC)) were tested. Selected heavy metal concentrations were measured in leaves, rhizomes and rooting soil of May lily in five beech forests of southern Poland, mainly including an industrialised region of Upper Silesia. The contamination level of these ecosystems was assessed with a single pollution index. The results show significant contamination with $\mathrm{Pb}$ even at control sites and moderate with $\mathrm{Cd}, \mathrm{Zn}, \mathrm{Fe}$ and $\mathrm{Cu}$ in Upper Silesian forests. May lily accumulated $\mathrm{Pb}, \mathrm{Zn}$ and Fe mainly in rhizomes, but $\mathrm{Ni}, \mathrm{Cu}$ and $\mathrm{Cd}$ were also translocated to aboveground organs in comparable quantities, which confirms the indicator value of this plant. May lily accumulated up to 21 and $30 \mathrm{mg} \mathrm{g}^{-1} \mathrm{Cd}, 34$ and $90 \mathrm{mg} \mathrm{g}^{-1} \mathrm{~Pb}$ and 250 and $553 \mathrm{mg} \mathrm{g}^{-1} \mathrm{Zn}$ in leaves and rhizomes respectively. Moreover, the accumulation factors show that May lily accumulates $\mathrm{Cd}$ in
\end{abstract}

K. Bierza $(\bowtie)$

Faculty of Natural Sciences, Institute of Biology,

Biotechnology and Environmental Protection,

University of Silesia in Katowice, Bankowa Street 7,

40-007 Katowice, Poland

e-mail: karolina.bierza@us.edu.pl above- and underground organs in higher amounts than found in soil. Although high concentrations of these toxic elements in tissues, no visible damages on plants were observed, also the measured functional traits show no apparent relationship with the pollution level.

Keywords Bioaccumulation - Heavy metals · Functional traits $\cdot$ Maianthemum bifolium $\cdot$ Soil pollution

\section{Introduction}

One of the most dangerous environmental pollutants are heavy metals. Apart from natural sources such as weathering of rocks or volcanic eruptions, their presence in the environment is related to human activity-industrialisation and urbanisation (Wang et al., 2020; Yuanan et al., 2020). Elevated concentrations of these elements are listed in areas of ore extraction and processing (Demková et al., 2017; Stefanowicz et al., 2014; Yang et al., 2018) and in areas affected by the emissions from various industries (Loska et al., 2004; Zhao et al., 2014), as well as in city centres (Burt et al., 2014; Cai et al., 2013; Zhao \& Li, 2013). Such is the situation in Upper Silesia-the southern region of Poland, which has undergone a strong anthropopression since the Middle Ages, which is connected with the presence of metal ores and coal in these areas (Cabała et al., 
2020). Although this region is strongly industrialised and urbanised, the forests cover about $31.9 \%$ of the area, playing an important role in purifying the atmosphere (Jamnická et al., 2013). In the last decades of the twentieth century, industrial pollution and environmental degradation in Poland were highest in Europe (Cole, 1991). Over the past years, the situation has improved significantly; however, the problems of urban pollution, road transport and low emissions are existing (Černikovský et al., 2016) and still in 2018, Poland was at the forefront of the $\mathrm{PM}_{10}$ and $\mathrm{PM}_{2,5}$ annual mean concentrations amongst European countries (Ortiz \& Guerreiro, 2020). Studies show that dust emissions are deposited during past decades in the organic level of forest soils, and their acidic reaction contributes to increased metal mobility in the soil and increases metal availability, and thus inclusion in biogeochemical cycles, amongst others, through plant tissue (Jamnická et al., 2007; Magiera et al., 2007).

The influence of heavy metals on living organisms has been studied on a biochemical level (effect on DNA (e.g. Kaur et al., 2014; Siddiqui, 2015) and intracellular enzyme activity (Panda et al., 2011)) and physiological level (such as photosynthetic activity (e.g. Bernardini et al., 2016; Vesley et al., 2012) and transpiration process (e.g. Haag-Kerwer et al., 1999; Singh \& Bhati, 2003)). Patterns of metal accumulation in tissues are also widely studied in order to identify indicator, accumulator or excluder plants for phytoremediation, monitoring or ecotoxicity evaluation purposes (e.g. Christou et al., 2017; Dinu et al., 2020; Sert et al., 2019). There are also studies on morphological plant traits; however, they are relatively few and often are performed in laboratory conditions (e.g. Islam et al., 2007; Ouzounidou et al., 1995; Todeschini et al., 2011). The study of plants in natural conditions is most often carried out in areas with very high concentrations of heavy metals in the soil, for example, in areas where metal ores are extracted and processed (e.g. Ashraf et al., 2011; Franiel \& Babczyńska, 2011; Wójcik et al., 2013). Nonetheless, such areas occupy a small percentage of the globe's surface (Bradshaw et al., 1989). Heavy metals, however, can affect plants even at low concentrations that do not cause visible damage (Ryser \& Sauder, 2006). Despite evidence of heavy metal toxicity to plants under laboratory conditions, their effect is less visible in natural conditions (Bezel' et al., 2001) but can provide real insight into the functioning of a given organism in the contaminated environment.

Functional plant traits can be defined as the morphological, physiological and phenological properties of plants, measurable from the cellular to the whole organism level, that potentially influence their fitness (Violle, 2007) or the environment they live in (Lavorel \& Garnier, 2002). These traits represent critical plant responses to environmental change and the fundamental influence of plants on ecosystem processes. They provide information for interpreting ecological and evolutionary theories and practical solutions for conservation and land management. At the same time, their analysis is relatively easy and cheap (Pérez-Harguindeguy et al., 2013). Universal traits underlying the life cycle of plants include plant size, usually measured by height as well as leaf structure, often represented as specific leaf area (SLA) or leaf dry matter content (LDMC) (Westoby, 1998). SLA of herbaceous plants such as Plantago lanceolata, Plantago major and Taraxacum officinale was used for pollution biomonitoring, presenting higher values in more urbanised, hence polluted, sites (Balasooriya et al., 2009; Datcu et al., 2017; Kardel et al., 2010). For example, SLA and LDMC were determined for plants from landfill waste from Ni smelter to determine their response to harsh environmental conditions (Čierniková et al., 2021).

The beech forest complexes had initially played an essential role in the forest ecosystems of Upper Silesia but are now significantly reduced. The best-preserved beech forests in the area are currently the acidic lowland beech forests (Luzulo pilosae-Fagetum) (Cabała et al., 2006; Parusel, 2011). The herb abundant in the herb layer of these forests is Maianthemum bifolium (L.) F.W. Schmidt. The species has a wide geographic range and is common throughout Europe and Asia to Japan (Kim \& Lee, 2007). It is known to show plastic morphological response to environmental stress but was investigated only in terms of naturally occurring environmental conditions such as different resource availability in contrasting forest habitats (Czarnecka, 1996) or forest sites contrasting with chemistry and light regime (D’Hertefeld \& Jonsdottir, 1994).

It was hypothesised that the long-lasting pollution in Silesian forests would affect the populations of May lily, changing the chemical composition of plants and, in consequence, causing changes in functional traits as a way to adapt to environmental 
conditions. This study aimed to (i) compare the ability of $M$. bifolium to accumulate heavy metals in leaves and rhizomes, (ii) estimate utility of $M$. bifolium in biomonitoring through accumulation of heavy metal in tissues and/or changes in chosen functional traits and (iii) assess the heavy metal contamination in three acid beech forest complexes in Upper Silesia against relatively unpolluted forests from southern Poland.

\section{Materials and Methods}

\subsection{The Species and the Study Area}

Maianthemum bifoilium (L.) F. W. Schmidt (May lily) is a monocotyledonous perennial herbaceous plant with underground rhizomes. The plant has vegetative shoots with a single leaf and sexual two-leafed shoots with one inflorescence. The predominant way of spreading is vegetative, through rhizomatous growth (D’Hertefeld \& Jonsdottir, 1994).

The study was performed in five Luzulo-Fagetum beech forests with $M$. bifolium abundant in the herb layer in southern Poland, differing in the level of pollution. Three of them were located within the Upper Silesian Industrial Region, influenced for many years by heavy industry and urbanisation due to various mineral resources (Kondracki, 2002). These are natural forest fragments, currently subjected to different forms of protection-Segiet (S), Uroczysko Buczyna (UB) and Murcki Forest (M)-formerly transformed through the exploitation of $\mathrm{Zn}-\mathrm{Pb}$ ores (Segiet) and coal mining (Murcki Forest, Uroczysko Buczyna) (Molenda, 2013). As control sites, forests relatively free from industrial pollution were chosen-Parkowe (P) and Wzgórze Joanny (WJ). Figure 1 presents the localisations of the sampling sites. The beech forests at the study sites are over 120 years old, mostly welldeveloped and preserved (Cabała et al., 2006). The annual mean temperature in Segiet, Uroczysko Buczyna, Murcki Forest and Parkowe sites is $8.1{ }^{\circ} \mathrm{C}$ with annual precipitation ranging from 620 to $890 \mathrm{~mm}$ (Woś, 2010), and for Wzgórze Joanny $8.8^{\circ} \mathrm{C}$ and 530-570 mm (Polechoński et al., 2018). The forest floor is scarce, beside the Maianthemum bifolium; patches of Vaccinium myrtillus, Luzula pilosa, Deschapmsia flexuosa, Oxalis acetosella and Convalaria majalis also occurred.

\subsection{Field Sampling and Plant Measurements}

As the May lily spreads mainly by the vegetative growth, it forms distinct patches, and the sampling plots were established in 16 of such patches ( 9 plots at the sites described as polluted and 7 at control sites), with the average coverage of May lily in the range of $40-60 \%$ per patch. The light conditions were similar at all sampling plots. All plots were sampled for topsoil, vegetative shoots and rhizomes. Plant sampling was conducted in July 2014 (at the full development of plants). Only plants with no mechanical damages to the leaf were collected. Rhizomes from $1-\mathrm{m}^{2}$ plots were excavated to be analysed in the laboratory. From 3 to 15 random samplings with $1-\mathrm{m}^{2}$ frame were performed at each sampling patch. After sampling, plants were immediately transported to the laboratory in a cooler bag, then rehydrated with deionised water. The fresh weight of the leaves and rhizomes was determined. The leaf area and rhizome internode length were measured, followed by drying at $70{ }^{\circ} \mathrm{C}$ to constant weight. Prepared plant material was subjected to measurements for the following traits: the height of vegetative shoots, specific leaf area (SLA), leaf dry matter content (LDMC), specific rhizome length (SRL) and rhizome dry matter content (RDMC). The measurements of the traits were conducted according to Pérez-Harguindeguy et al. (2013) and Birouste et al. (2014). As a component of SLA, leaf area was measured using the ImageJ software (National Institute of Health, Bethesda, MD, USA). In total, 1863 vegetative shoots and 1494 rhizome internodes were measured.

\subsection{Soil and Plant Chemical Analyses}

Soil samples were taken from the topsoil $(0-10 \mathrm{~cm})$ in five replications per May lily patch and combined into one composite sample per patch (altogether 16 samples). The $\mathrm{pH}\left(\mathrm{pH}_{\mathrm{KCl}}\right)$ was determined in each sample, and the organic matter content was measured by the loss-on-ignition (LOI). Soil samples after overnight drying at $105{ }^{\circ} \mathrm{C}$ were weighed and placed in a furnace at $550{ }^{\circ} \mathrm{C}$ for $8 \mathrm{~h}$. After combustion, the samples were re-weight, and the percentage of the dry weight loss was calculated (Salehi et al. 2011). Soil total nitrogen was analysed using the Kjeldahl digestion procedure (Rutherford et al., 2007) and available phosphorus and potassium 
Fig. 1 Location of the sampling sites (the symbols in frames are the control sites)

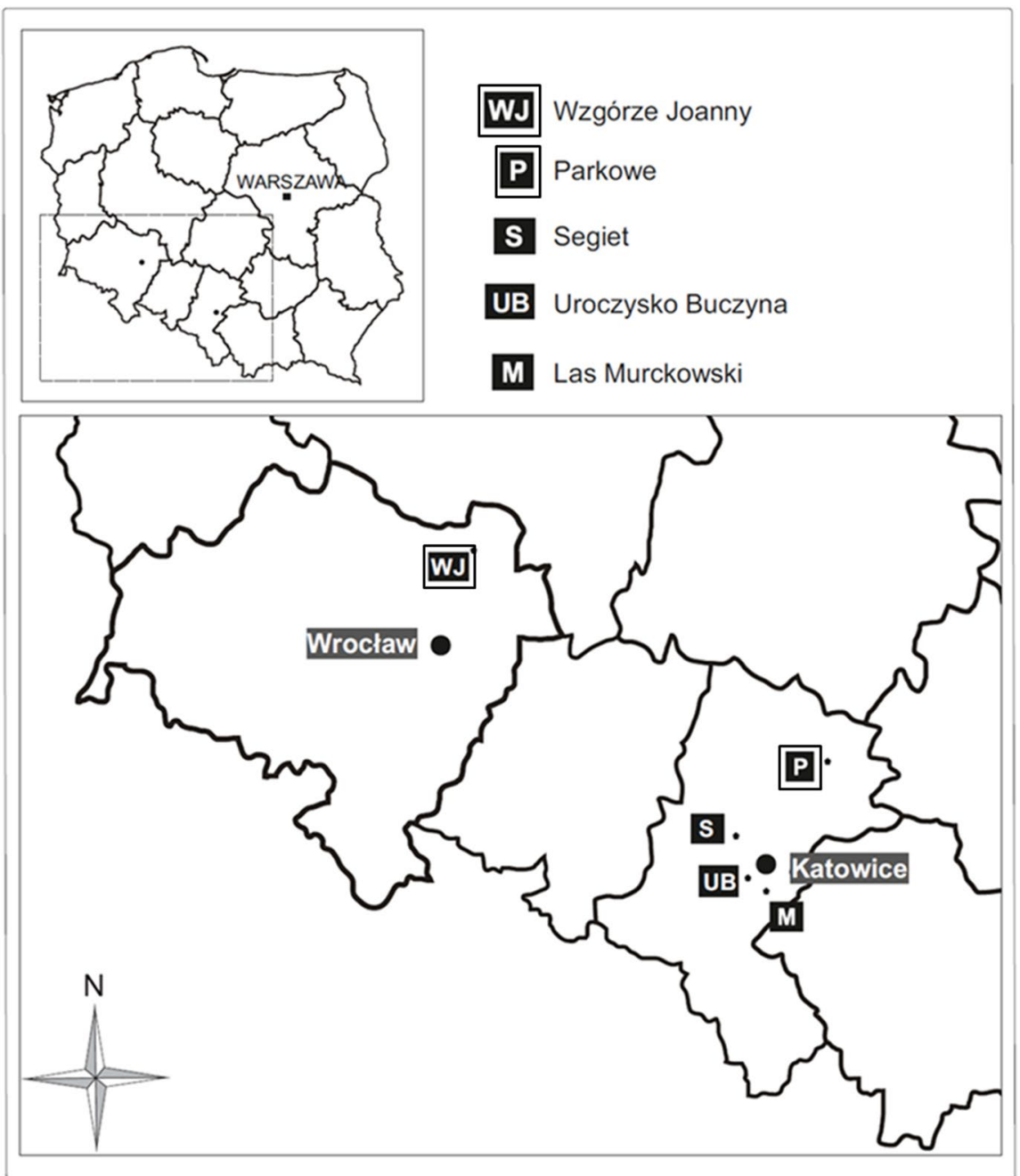

contents by the Egner-Rhiem method. The total concentrations of $\mathrm{Cd}, \mathrm{Pb}, \mathrm{Zn}, \mathrm{Ni}, \mathrm{Fe}$ and $\mathrm{Cu}$ were estimated according to Sastre et al. (2002). More precisely, $0.25 \mathrm{~g}$ of soil was mineralised in $8 \mathrm{ml}$ of concentrated $\mathrm{HNO}_{3}$ and $2 \mathrm{ml}$ of $30 \% \mathrm{H}_{2} \mathrm{O}_{2}$ in a microwave oven (Milestone Ethos One, Italy) at $190{ }^{\circ} \mathrm{C}$. After mineralisation, samples were diluted to $25 \mathrm{ml}$ with deionised water and filtered. The potentially bioavailable fraction of heavy metals was extracted with $0.01 \mathrm{M} \mathrm{CaCl}_{2}$ after shaking $5 \mathrm{~g}$ of soil with $50 \mathrm{ml}$ of $\mathrm{CaCl}_{2}$ for $2 \mathrm{~h}$ (Wójcik et al., 2014). The content of metals was determined in the filtered extracts by atomic absorption spectroscopy (Thermo Scientific ICE 3000 Series). All of the analyses included blank samples and certified reference materials (NCS DC 77,302, China National
Analysis Centre for Iron and Steel) to ensure the quality of the analyses. Each measurement was conducted in three replications.

Contamination of the forest soils by heavy metals was assessed using the single factor pollution index (PI) as follows:

$P I=C_{i} / S_{i}$,

where $C_{i}$ is the concentration related to the investigated site and $S_{i}$ is the background value for Upper Silesia soils, for $\mathrm{Pb}, \mathrm{Zn}, \mathrm{Cd}$ and $\mathrm{Cu}$ according to Pasieczna et al. (2010); due to lack of literature data for $\mathrm{Fe}$ and $\mathrm{Ni}$, the lowest values determined in the control areas were taken as background values. Table 1 presents the classes of the pollution index (PI) according to $\mathrm{Hu}$ et al. (2017). 
Table 1 Classes of pollution level according to PI values

\begin{tabular}{lll}
\hline Class & $P I$ & Class of pollution \\
\hline 1 & $\leq 1.0$ & Safety \\
2 & $1.0<\mathrm{PI} \leq 2.0$ & Slight pollution \\
3 & $2.0<\mathrm{PI} \leq 3.0$ & Mild pollution \\
4 & $3.0<\mathrm{PI} \leq 5.0$ & Moderate pollution \\
5 & $\mathrm{PI}>5$ & Severe pollution \\
\hline
\end{tabular}

Since the studies were conducted in natural ecosystems, and all investigated heavy metals were affecting the plants, the pollution level for each study site was also calculated as integrated pollution index (IPI) (Chen et al., 2005).

$\mathrm{IPI}=\frac{\sum P I_{i}}{n}$

where $P I_{i}$ is the pollution index for each investigated heavy metal and $n$ is the number of investigated heavy metals. The IPI values were used in ordination analysis. IPI values together with PI are presented in Table 2.

Plant material (leaves and rhizomes) was collected at each sampling plot (ca. $50 \mathrm{~g}$ f.w) (altogether 16 samples of leaves and 16 samples of rhizomes). Concentrations of $\mathrm{Cd}, \mathrm{Pb}, \mathrm{Zn}, \mathrm{Ni}, \mathrm{Fe}$ and $\mathrm{Cu}$ in aboveground and underground parts of $M$. bifolium were analysed in $0.25-\mathrm{g}$ samples dried at $105{ }^{\circ} \mathrm{C}$, ground and mineralised in concentrated nitric acid and $30 \%$ $\mathrm{H}_{2} \mathrm{O}_{2}$ at $190{ }^{\circ} \mathrm{C}$ using a microwave oven (Milestone Ethos One, Italy). After mineralisation, samples were diluted with deionised water to a volume of $25 \mathrm{ml}$. The concentration of heavy metals was determined by atomic absorption spectroscopy (Thermo Scientific ICE 3000 Series). The reference material (certified reference material CTA-OTL-1 Oriental Tobacco Leaves) was used to evaluate the quality of the analytic procedure. Each measurement was conducted in three replications.

The ability to accumulate heavy metals in the leaves and rhizomes of $M$. bifolium was assessed by calculating the bioconcentration (BCF) and the bioaccumulation (BAC) factors and the mobility of elements in plants by the translocation factor (TF) (Arifin et al., 2012; Rezvani \& Zaefarian, 2011).

$B C F=[\text { traceelement }]_{\text {rhizome }} /[\text { traceelement }]_{\text {soil }}$

$B A C=[\text { traceelement }]_{\text {leaves }} /[\text { traceelement }]_{\text {soil }}$

$T F=[\text { traceelement }]_{\text {leaves }} /[\text { traceelement }]_{\text {rhizomes }}$

A value of $\mathrm{BAC}>1$ indicates the ability to accumulate the element, whilst $\mathrm{BAC}<1$ indicates exclusion of the element by the plant. A value of $\mathrm{TF}>1$ indicates translocation of the element from underground to aboveground organs.

\subsection{Statistical Analyses}

To obtain the normal distribution of data, the BoxCox transformation was used (mean values of each trait presented in tables and figures are non-transformed). The differences between the heavy metal content in soils, plant organs and plant functional traits were tested using ANOVA, and when the significant differences were identified, a post hoc test (Tukey HSD) was performed. Relationships amongst soil and plant metal concentrations were analysed using Pearson's correlation analysis. The analyses were conducted with Statistica v.12.

The ordination analyses were performed to evaluate the influence of chemical and biological properties of the investigated habitat on the chosen $M$. bifolium functional traits. The functional traits of plants from the sampling plots were used as separate
Table 2 Pollution indices of investigated metals in beech forest soils

\begin{tabular}{|c|c|c|c|c|c|c|c|}
\hline & \multicolumn{6}{|l|}{$P I$} & \multirow[t]{2}{*}{ IPI } \\
\hline & $\mathrm{Cd}$ & $\mathrm{Pb}$ & $\mathrm{Zn}$ & $\mathrm{Fe}$ & $\mathrm{Cu}$ & $\mathrm{Ni}$ & \\
\hline$S$ & 4.4 & 40.9 & 7.4 & 2.9 & 4.4 & 2.0 & 10.8 \\
\hline UB & 2.9 & 17.4 & 3.8 & 3.3 & 3.4 & 2.1 & 6.9 \\
\hline M & 2.0 & 22.7 & 3.1 & 2.8 & 3.8 & 2.2 & 6.4 \\
\hline $\mathrm{P}$ & 0.4 & 4.8 & 0.7 & 1.0 & 1.0 & 1.0 & 1.7 \\
\hline WJ & 0.4 & 3.6 & 0.8 & 1.3 & 2.8 & 1.2 & 2.0 \\
\hline
\end{tabular}


variables with $\log$ transformation $\mathrm{Y}=\log (\mathrm{Ay}+\mathrm{C})$. The detrended canonical analysis (DCA) revealed the gradient length lower than 3SD (0.187), which indicates the linear structure of the data and therefore allows to use the redundancy analysis (RDA) in further analyses. As the environmental variables in the redundancy analysis, the chemical properties of the soil, including the integrated pollution index, were used. RDA was followed by the forward stepwise selection of environmental variables and the unrestricted Monte Carlo test with 499 permutations. The ordination analyses were performed with the Canoco v 4.5 package (Ter Braak \& Smilauer, 2002).

\section{Results and Discussion}

\subsection{Basic Soil Properties}

The physicochemical properties of sampling sites are presented in Table 3. All of the sites were characterised with acidic soil $\mathrm{pH}$ (from 2.95 to 3.59). Soils at the UB and $\mathrm{M}$ sites can be classified as organic (over $30 \%$ organic matter) whilst $\mathrm{S}, \mathrm{P}$ and $\mathrm{WJ}$ as mineral (from 4.5 to 7.9) (Bednarek et al., 2004). The content of the macroelements $(\mathrm{N}, \mathrm{P}, \mathrm{K})$ was higher in organic soils of UB and M sites.

\subsection{Heavy Metal Content in Investigated Soils}

The studies of heavy metal pollution of the forest ecosystems soils show that pollutants entering the soil are accumulated mainly in the surface layer of organic soil (Jamnická et al., 2007; Magiera et al., 2007). The total fraction of the investigated heavy metals in soils showed significant differences between the polluted and the unpolluted sites in the case of almost all elements. Only $\mathrm{Cu}$ concentration at the WJ control site did not differ from UB and M sites. Amongst the investigated soils, the highest concentrations concerned $\mathrm{Fe}$ and $\mathrm{Pb}$ even at the control sites. $\mathrm{Ni}$ and $\mathrm{Cd}$ occurred in the lowest concentrations.

The concentrations of $\mathrm{Cd}, \mathrm{Pb}$ and $\mathrm{Zn}$ at the polluted sites have multiple times exceeded the values obtained for the control sites, which are reflected by very high PI values (Table 2). The Upper Silesian forests are severely polluted with $\mathrm{Pb}$, also the $\mathrm{Cd}, \mathrm{Zn}$ and $\mathrm{Cu}$ pollution is considerable. However, the concentrations of $\mathrm{Pb}$ at the control sites also indicate moderate pollution with this element. According to the PI index, the WJ control site is mildly polluted with $\mathrm{Cu}$, and the $\mathrm{Fe}$ and $\mathrm{Ni}$ contamination at all polluted sites is mild.

Amongst the investigated communities in the upper soil layer, significantly elevated $\mathrm{Cd}, \mathrm{Pb}$ and $\mathrm{Zn}$ concentrations were found in the $\mathrm{S}$ site, which exceeded the concentrations recorded in soils in relatively free of pollution sampling sites, 11, 9.5 and 8.5 times, respectively. At this location, considerable heavy metal pollution is connected with the proximity (about $15 \mathrm{~km}$ ) of the zinc smelter in Miasteczko Śląskie and centuries of mining and processing of $\mathrm{Zn}$ and $\mathrm{Pb}$ ores in this area (Ullrich et al., 1999). At the $\mathrm{S}$ site, the forest is growing on the old $\mathrm{Zn}$ and $\mathrm{Pb}$ ore excavation area, which is considered as a source of environmental pollution-soils developed at such locations might be highly polluted with $\mathrm{As}, \mathrm{Cd}, \mathrm{Pb}$ and Zn (Stefanowicz et al., 2014, 2016).

$\mathrm{Pb}$ concentrations in the soil, potentially toxic to plants, are considered values above $500 \mathrm{mg} \mathrm{kg}^{-1}$ (Kabata-Pendias \& Pendias, 1999). These values were exceeded at the $\mathrm{S}$ and $\mathrm{M}$ sites. Also, a significant incensement in $\mathrm{Cd}$ concentration in the Upper Silesian forest ecosystems was observed. The obtained results of $\mathrm{Cd}, \mathrm{Pb}, \mathrm{Zn}$ and Ni concentrations in investigated forests are similar to values obtained in nearby Silesian forests (Magiera et al., 2007). Generally, the soils of Upper Silesia are in varying

Table 3 Physicochemical properties of the soil (mean values \pm SD)

\begin{tabular}{lclllllll}
\hline Site & $\mathrm{C}[\%]$ & $\mathrm{N}[\%]$ & $\mathrm{C} / \mathrm{N}$ & $\mathrm{P}_{2} \mathrm{O}_{5}[\mathrm{mg} / 100 \mathrm{~g}]$ & $\mathrm{K}_{2} \mathrm{O}[\mathrm{mg} / 100 \mathrm{~g}]$ & $\mathrm{Ca}\left[\mathrm{g} \mathrm{kg}^{-1}\right]$ & $\left.\mathrm{Mg}^{\mathrm{g} \mathrm{kg}}{ }^{-1}\right]$ & $\mathrm{pH}$ \\
\hline $\mathrm{S}$ & $7.45 \pm 2.6$ & $1.01 \pm 0.1$ & 7.21 & $23.33 \pm 3.3$ & $21.97 \pm 2.9$ & $2.27 \pm 0.34$ & $1.26 \pm 0.04$ & 3.51 \\
$\mathrm{UB}$ & $36.35 \pm 2.6$ & $1.01 \pm 0.1$ & 36.64 & $62.44 \pm 8.5$ & $55.07 \pm 5.0$ & $1.27 \pm 0.06$ & $1.18 \pm 0.06$ & 3.59 \\
$\mathrm{M}$ & $30.97 \pm 11.9$ & $1.99 \pm 0.6$ & 15.30 & $21.21 \pm 15.0$ & $42.18 \pm 9.9$ & $1.29 \pm 0.41$ & $0.90 \pm 0.19$ & 3.07 \\
$\mathrm{P}$ & $7.92 \pm 0.7$ & $0.76 \pm 0.2$ & 11.52 & $19.17 \pm 5.6$ & $18.88 \pm 3.2$ & $1.53 \pm 0.16$ & $0.67 \pm 0.06$ & 2.95 \\
$\mathrm{WJ}$ & $4.52 \pm 1.8$ & $0.77 \pm 0.3$ & 6.02 & $1.88 \pm 1.0$ & $17.15 \pm 1.9$ & $1.28 \pm 0.3$ & $1.27 \pm 0.4$ & 3.33 \\
\hline
\end{tabular}


degrees contaminated with heavy metals, which results firstly from the geological construction of the region, namely the occurrence of zinc-lead ore deposits (Lis \& Pasieczna, 1997) and the resulting industrial activities. Concentrations of heavy metals in the surface soils of the control sites were only a fraction of heavy metal concentration levels in Upper Silesia soils, demonstrating a relatively low exposure to metalliferous pollution.

The concentrations of the bioavailable fraction of heavy metals varied depending on the element. $\mathrm{Cd}$ had the highest level of bioavailability (up to $26 \%$ of the total content of the element in the soil), followed by $\mathrm{Zn}$ (up to $14 \%$ of the total fraction) and $\mathrm{Ni}$ (3.8\%). The availability of $\mathrm{Pb}, \mathrm{Cu}$ and $\mathrm{Fe}$ was low and ranged from $1.5,1.1$ to $0.1 \%$ of the total content of these elements, respectively (Table 4). The bioavailability of the investigated heavy metals was in the typical ranges estimated for forest soils (Kim et al., 2015). In the case of all elements besides Fe, it correlated mainly with the total metal concentration, and in the case of $\mathrm{Cd}, \mathrm{Zn}$ and $\mathrm{Fe}$ with soil $\mathrm{pH}$. The highest bioavailability of $\mathrm{Cd}, \mathrm{Zn}, \mathrm{Pb}$ and $\mathrm{Cu}$ was observed at the control $\mathrm{P}$ site, presumably related to the lowest $\mathrm{pH}$ and relatively low organic matter content at this location. These soil properties enhance mental availability (Shahid et al., 2016).

\subsection{Heavy Metals in Leaves and Rhizomes of Maianthemum bifolium}

The concentrations of heavy metals in the rhizomes and leaves of the May lily plants collected from the polluted $(\mathrm{S}, \mathrm{UB}, \mathrm{M})$ and control sites $(\mathrm{P}, \mathrm{WJ})$ are presented in Table 5. The highest levels concerned Fe and $\mathrm{Zn}$, both in aboveground and underground plant parts. The greatest concentration of investigated elements, except for $\mathrm{Cu}$ at the control sites, was found in the rhizomes. Ni was found in the lowest concentrations in leaves as well as rhizomes. The concentrations in leaves and rhizomes were significantly higher for the polluted sites than the control sites. The concentrations assessed for the unpolluted regions did not differ from the ranges reported in other pollutionfree regions of Poland (Kozanecka et al., 2002). The general pattern of metal concentration in $M$. bifolium organs was similar to that found in wetland species (Deng et al., 2004) and in plants growing near highways (Huseyinova et al., 2009), as well as in plants

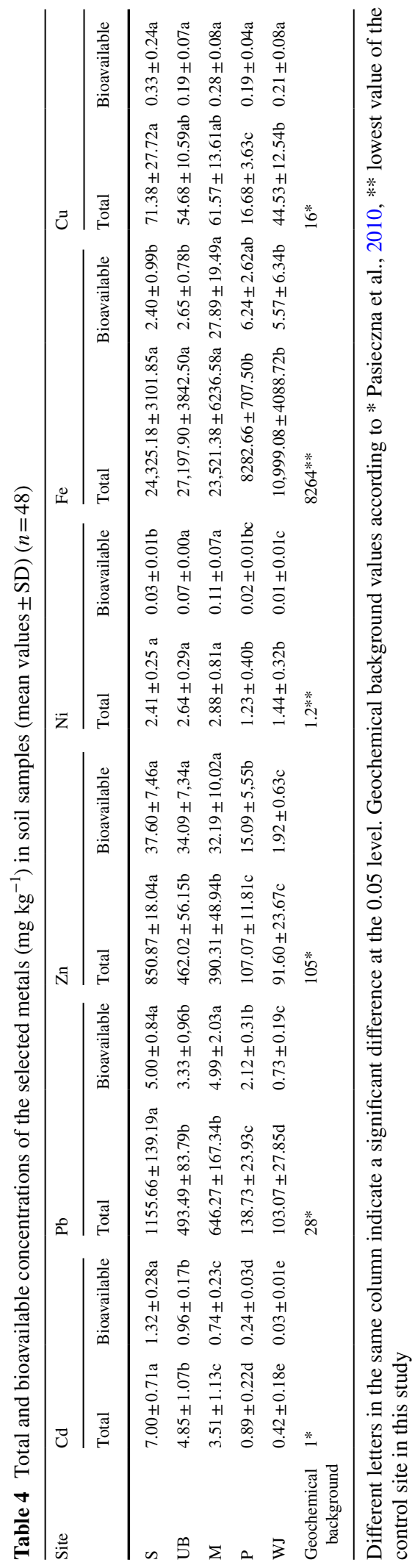




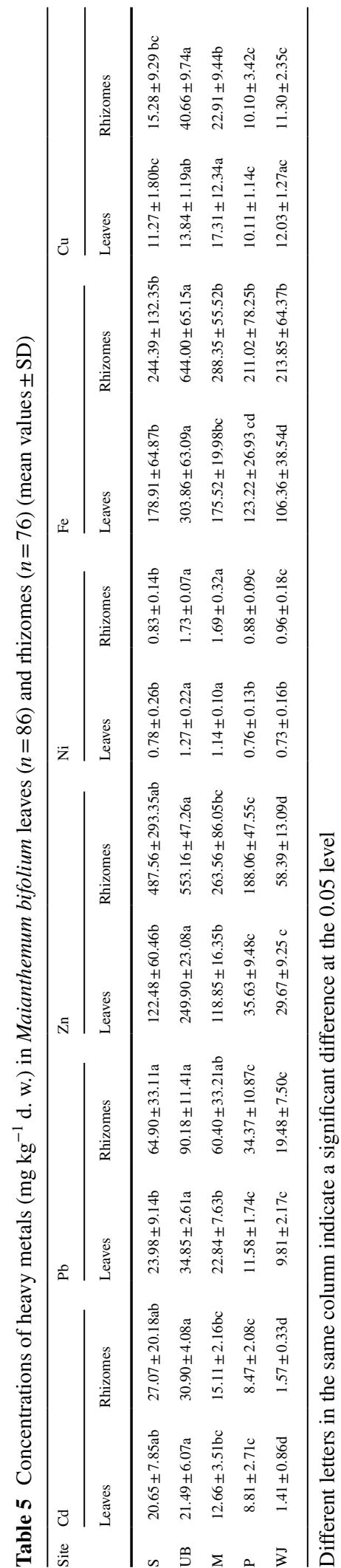

from the understory of beech forests on former $\mathrm{Zn}-\mathrm{Pn}$ mines (Luwe, 1995; Stefanowicz et al., 2016). However, the element's accumulation in the leaves differed between the polluted and control sites and can be presented in different orders. For the control sites, the highest concentrations were of the essential elements $\mathrm{Fe}>\mathrm{Zn}>\mathrm{Cu}>\mathrm{Pb}>\mathrm{Cd}>\mathrm{Ni}$, whilst for the polluted ones, the concentrations were as follows: $\mathrm{Fe}>\mathrm{Zn}>\mathrm{Pb}>\mathrm{Cd}>\mathrm{Cu}>\mathrm{Ni}$, despite the high bioavailability of $\mathrm{Cd}$ and the low bioavailability of $\mathrm{Pb}$. In rhizomes of plants growing at the polluted sites, $\mathrm{Zn}$ prevailed over $\mathrm{Fe}$, whilst the rest of the element's content decreased as follows: $\mathrm{Pb}, \mathrm{Cu}, \mathrm{Cd}$ and $\mathrm{Ni}$.

The concentration of investigated elements in plant tissues depended mainly on their soil concertation. The positive and statistically significant correlation between heavy metal content in soil and leaves and the May lily rhizomes was obtained in all elements studied besides $\mathrm{Cu}$ in above- and underground organs and $\mathrm{Pb}$ in rhizomes. A strong correlation was found for $\mathrm{Cd}$ and Fe content in soil and leaves (Tables 6 and 7).

Cd phytotoxic concentrations are reported at $5-10 \mathrm{mg} \mathrm{kg}^{-1}$ for susceptible plants, whilst 10-30 mg kg${ }^{-1}$ for resistant plants (Kabata-Pendias \& Pendias, 1999). This study determined cadmium concentration values above $10 \mathrm{mg} \mathrm{kg}^{-1}$ even in plants from control plots, and values exceeding $30 \mathrm{mg} \mathrm{kg}^{-1}$ characterised plants from the $\mathrm{S}$ and UB sites. These results suggest that $M$. bifolium is relatively resistant to the elements mentioned above, as no visible traces of damage to leaves or underground organs were observed. Moreover, high bioaccumulation factors (BAC, BCF) indicate increased cadmium uptake, which concentrations in the plant exceeded those in the soil. On average, the Cd concentration in the rhizomes was almost six times as high, and in aboveground organs, and 4.2 times as high as in the soil, which can describe $M$. bifolium as an accumulator of this element (Mehes-Smith et al., 2013). These findings are consistent with the research conducted near Finnish steelworks (Mukherjee \& Nuorteva, 1994), in which the ability of $M$. bifolium to accumulate $\mathrm{Cd}$ was also reported. Concentrations of $\mathrm{Zn}$ above the value of $100 \mathrm{mg} \mathrm{kg}^{-1}$, especially at the UB site reaching $600 \mathrm{mg} \mathrm{kg}^{-1}$ in underground parts, are considered toxic (Kabata-Pendias \& Pendias, 1999). Comparing the accumulation coefficients of the other elements, apart from $\mathrm{Cd}$, only $\mathrm{Zn}$ was characterised by 
Table 6 Pearson's correlation coefficients between heavy metals in leaves, rhizomes and soils of Maianthemum bifolium

\begin{tabular}{lllllll}
\hline & $\mathrm{Cd}$ & $\mathrm{Pb}$ & $\mathrm{Zn}$ & $\mathrm{Fe}$ & $\mathrm{Cu}$ & $\mathrm{Ni}$ \\
\hline Leaves - soil $(N=18)$ & $0.793^{* * *}$ & $0.562^{*}$ & $0.586^{*}$ & $0.749 * * *$ & 0.377 & $0.671^{* *}$ \\
Rhizomes - soil $(N=17)$ & $0.561 *$ & 0.351 & $0.589^{*}$ & $0.497 *$ & 0.467 & $0.626 * *$ \\
Leaves - rhizomes $(N=70)$ & $0.874 * * *$ & $0.597 * * *$ & $0.663^{* * *}$ & $0.743 * * *$ & 0.159 & $0.711^{* * *}$ \\
\hline
\end{tabular}

**** $p<0.001, * * p<0.01$ and $* p<0.05$

Table 7 Heavy metal translocation factor (TF), bioconcentration factor (BCF) and bioaccumulation factor (BAC) in Maianthemum bifolium

\begin{tabular}{lllllll}
\hline & $\mathrm{Cd}$ & $\mathrm{Pb}$ & $\mathrm{Zn}$ & $\mathrm{Ni}$ & $\mathrm{Fe}$ & $\mathrm{Cu}$ \\
\hline $\mathrm{TF}$ & 0.74 & 0.40 & 0.37 & 0.76 & 0.58 & 0.76 \\
$\mathrm{BCF}$ & 5.68 & 0.12 & 0.96 & 0.60 & 0.02 & 0.44 \\
$\mathrm{BAC}$ & 4.24 & 0.05 & 0.33 & 0.45 & 0.01 & 0.31 \\
\hline
\end{tabular}

the values of bioaccumulation coefficients higher than 1 (at UB and P sites, data not shown), signalling the ability of May lily to accumulate this element as well. Despite higher concentrations of $\mathrm{Pb}, \mathrm{Ni}, \mathrm{Fe}$ and $\mathrm{Cu}$ in plants from the polluted area, phytotoxic concentrations of these elements were not exceeded. However, the content of $\mathrm{Cd}, \mathrm{Pb}$ and $\mathrm{Zn}$ was many times higher than in plants collected from the $\mathrm{P}$ and $\mathrm{WJ}$ sites, reflecting soil pollution in the studied areas. The ability to accumulate toxic metals was also reported in other understory plants such as Mycelis muralis, Melica nutans and Mercurialis perennis in beech forests growing on former mining areas and no visible negative effect on plant growth (no necrosis, chlorosis) was observed (Luwe, 1995; Stefanowicz et al., 2016; Woch et al., 2017). Nevertheless, these findings confirm that some heavy metals might be transferred to higher trophic levels and potentially cause adverse effects for the herbivores.

Conducted analyses of heavy metal concentrations in $M$. bifoilium tissues also showed differences in underground and aboveground organs. The value of the translocation factor $(\mathrm{TF}<1)$ indicates that $M$. bifoilium, like many other plant species, accumulates heavy metals in underground parts (Jamnická et al., 2013; Stefanowicz et al., 2016; Wójcik \& Tukiendorf, 2005) as an "exclusion" strategy, protecting plants from the harmful effects of excess of these elements. The lowest translocation factor values referred to $\mathrm{Zn}$ and $\mathrm{Pb}$, followed by $\mathrm{Fe} . \mathrm{Pb}$ is not very mobile in the soil and the plant and is usually accumulated in the roots (Ociepa-Kubicka \& Ociepa, 2012). Fe behaves similarly to the $\mathrm{Pb}$ in the plant (Kabata-Pendias \& Pendias, 1999). Also, Zn and Cd are usually accumulated in underground organs (Jamnická et al., 2013; Klink et al., 2013; Yoon et al., 2006). Cd, Ni and Cu are almost equally distributed in the aboveground and underground organs, and therefore the TF is relatively high ( $>0.7)$ and confirms the indicator value of May lily (Oliva \& Espinosa, 2007). The TF of $\mathrm{Cu}$ in plant tissues from control sites reached values $>1$ (data not shown), indicating the accumulation of this element in aboveground parts. This strategy also applies to other forest floor plants such as Mercurialis perennis and Polygonatum multiflorum (Luwe, 1995), Carex pilosa, Galium odoratum or Dentaria bulbifera (Jamnická et al., 2013). Studies show that copper is sometimes accumulated in similar concentrations in aboveground and underground parts (Chakroun et al., 2010). An increase in its accumulation in underground organs is associated with an increase in its concentration in the soil (Madejón et al., 2003). Such is the situation observed for the studied species in areas with elevated heavy metal concentrations. The translocation of $\mathrm{Cu}$ to aboveground organs may be due to the essential functions of this element in the plant body, being a structural element of proteins and involved in electron transport during photosynthesis, mitochondrial respiration, response to oxidative stress, cell wall metabolism or hormonal signalling (Yruela, 2005). Relatively high translocation rates associated with $\mathrm{Ni}$ may result from its high 
Fig. 2 Mean values of investigated functional traits of Maianthemum bifolium. Different letters in one figure indicated a significant difference at $p<0.05$ (orange - polluted sites, green control sites)

mobility in plants (Kabata-Pendias \& Pendias, 1999). Concentrations of this element determined in organs of herbaceous plants from southern areas of Poland showed similar concentrations in leaves and roots, or concentrations slightly higher in underground organs (Łaszewska et al., 2007).

\subsection{Functional Traits}

Figure 2 presents the mean values of measured functional traits of May lily across the investigated populations. The height of plants ranged from $4.8 \mathrm{~cm}$ at the $\mathrm{M}$ site to $7 \mathrm{~cm}$ at the $\mathrm{P}$ and WJ sites. The SLA index reached its highest value in the $\mathrm{M}$ and $\mathrm{WJ}$ population (40.3 and $38.5 \mathrm{~mm}^{2} \mathrm{mg}^{-1}$ respectively). The lowest value of the index was characteristic for the leaves of the UB and S populations (32.5 and $33.15 \mathrm{~mm}^{2} \mathrm{mg}^{-1}$ respectively), whilst plants from the same populations had the highest content of dry matter in tissues (LDMC) - at UB site 210 and S site $199 \mathrm{mg} \mathrm{g}^{-1}$. In the rhizome traits, the highest SRL value was obtained for the $S$ population $\left(4.9 \mathrm{~mm} \mathrm{~g}^{-1}\right)$, the lowest for the WJ population $\left(2.9 \mathrm{~mm} \mathrm{~g}^{-1}\right)$. Similar to the dry matter content in the aboveground tissues, the highest RDMC was calculated for the UB population $\left(354.4 \mathrm{mg} \mathrm{g}^{-1}\right)$. The lowest values were found in the WJ population (279 $\mathrm{mg} \mathrm{g}^{-1}$ ).

RDA was performed to identify whether physiochemical soil properties influenced the May lily traits (Fig. 3). The first axis, which represents the fertility of soils, explains $30.4 \%$ of the total variation in the measured traits. The second axis represents the heavy metal pollution gradient and explains $20.6 \%$ of the total variation. Amongst the six variables taken into consideration in the analysis, only the concentration of available $\mathrm{K}$ significantly influenced the investigated May lily functional traits (Lambda $\mathrm{A}=0.26$, $p=0.006$ ), and its effect explains $26 \%$ of the general variance. According to the analysis, the investigated functional traits of May lily were in a slight degree associated with metal pollution. Although the height of plants measured at the control sites was greater than at the polluted sites, there was no significant correlation with the integrated pollution index (neither
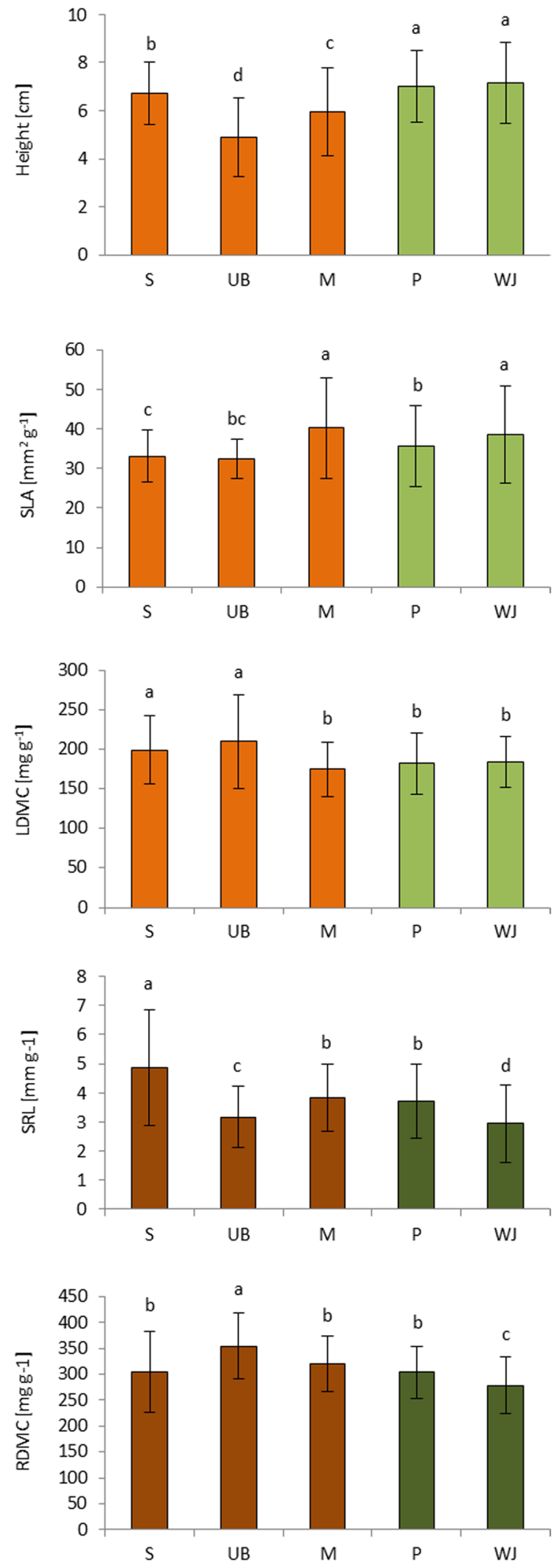


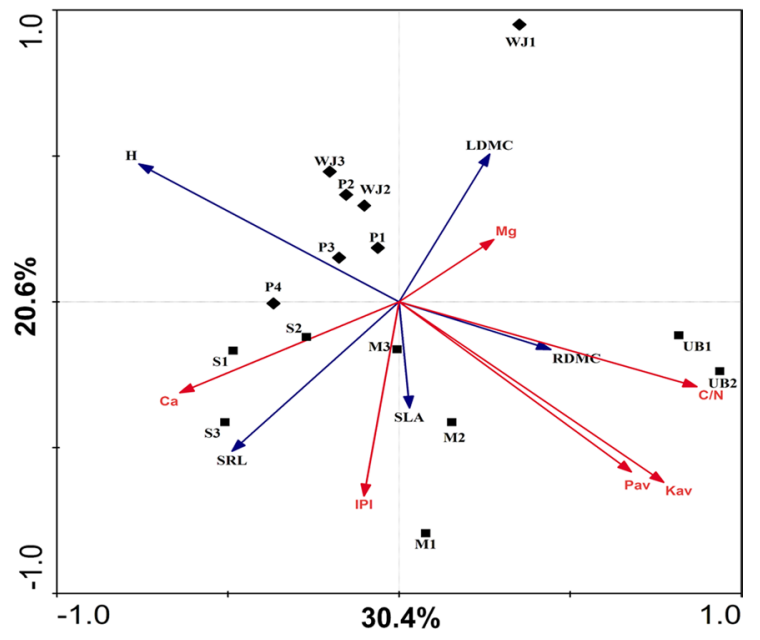

Fig. 3 The relationships between environmental variables (red arrows) at sampling points (diamonds represent the control sites $\mathrm{P}$ and $\mathrm{WJ}$; squares, the polluted sites $\mathrm{S}, \mathrm{UB}$ and $\mathrm{M}$ ) and the functional traits (blue arrows). LDMC - leaf dry matter content, RDMC - rhizome dry matter content, SLA - specific leaf area, SRL - specific rhizome length, $\mathrm{H}$ - height, Pav - available phosphorus, Kav - available potassium, IPI - integrated pollution index

with investigated elements, data not shown). In experimental conditions, $\mathrm{Cd}$ and $\mathrm{Zn}$ were found to reduce plant height (Chaves et al., 2011), although many species do not show any alterations in their morphological traits (e.g. Papazoglou et al., 2005; JiménezAmbriz et al., 2007). Meta-analysis of growth characteristics of plants growing near point polluters showed that growth reduction concerned only annual herbaceous plants (Zvereva et al., 2010). The higher pollution level might influence SRL and LDMC; at the polluted stands, the rhizomes were longer and thinner (higher SRL), and leaves had a higher level of hydration (lower LDMC). Higher SRL and SLA are connected with fast growth, usually at resource-rich sites (Shovon et al., 2020). Elongation of rhizomes might also be a strategy of avoiding unfavourable conditions (Oborny, 1994; Skálová et al., 1997), but it can only speculate whether heavy metals were related to this process. Studies on Alternaria philoxeroides and A. sesillis showed that $\mathrm{Cd}$ treatment negatively impacted plant traits, including internode length (Wang et al., 2021). Pb also had a negative effect on rhizome internode elongation in Phragmites australis; however, the reductions were reduced after a more extended period of the experiment, which was explained compensation to loss caused by disturbances in early stages of growth (Zhang et al., 2015). Under Ni and $\mathrm{Cu}$ treatment, length of stolon internodes of Potentilla anserina was not affected with heavy metals; however, they were thinner in relation to controls (Koivunen et al., 2004). Nonetheless, it should be stressed that the studies cited were carried out under experimental conditions, whilst data collected under natural conditions are very scarce. Higher RDMC indicates a resource-conservative strategy at resource-poor sites (Birouste et al., 2014) observed at nitrogen-poor UB site (C/N over 30 indicates low availability of $\mathrm{N})$. Presumably, biotic factors such as soil fertility and light availability predominantly affect plant traits at sites with a long contamination history. As the beech forests naturally colonise such areas in southern Poland in the natural succession, Woch et al. (2017) hypothesised that the accompanying plants might have some opportunities to form local metal-tolerant populations, which might also occur in the presented study.

\section{Conclusions}

The studies were conducted in natural forest habitats that had arisen in areas formerly entirely transformed by the exploitation of mineral deposits and which have returned to the biocenoses that are characteristic of these areas after human activity ceased. Therefore, levels of soil heavy metals are relatively high. Although clean technologies nowadays replace the heavy industry, their effects remain in the ecosystems, reflected by severe pollution with $\mathrm{Pb}$, moderate pollution with $\mathrm{Cd}, \mathrm{Zn}$ and $\mathrm{Cu}$, even at forests relatively distant from the polluters. Hence, the concentrations of heavy metals recorded in the tissues of May lily from polluted populations were elevated. Generally, the investigated elements were accumulated in the underground parts, but $\mathrm{Cd}, \mathrm{Cu}$ and $\mathrm{Ni}$ were translocated to the aboveground parts. Therefore this species can be proposed as an indicator plant in forest ecosystems. May lily has also shown a distinct capacity to accumulate cadmium at concentrations much higher than those found in soils. There was no clear evidence that heavy metal pollution has adverse effects on the functional traits of May lily. In natural conditions, the biotic factors probably play the primary role in displaying the morphological traits, and plants have adapted to the long-lasting pollution. 
Acknowledgements I am grateful to Dr Wojciech Bierza for his field and laboratory assistance. I would like to thank the reviewers for their valuable comments and advice.

Author Contribution Conceptualisation, methodology, analysis and investigation and writing the manuscript - Karolina Bierza.

Data Availability The datasets generated during and/or analysed during the current study are available from the corresponding author on reasonable request.

Code Availability Not applicable.

\section{Declarations}

Conflict of Interest The author declares no competing interests.

Open Access This article is licensed under a Creative Commons Attribution 4.0 International License, which permits use, sharing, adaptation, distribution and reproduction in any medium or format, as long as you give appropriate credit to the original author(s) and the source, provide a link to the Creative Commons licence, and indicate if changes were made. The images or other third party material in this article are included in the article's Creative Commons licence, unless indicated otherwise in a credit line to the material. If material is not included in the article's Creative Commons licence and your intended use is not permitted by statutory regulation or exceeds the permitted use, you will need to obtain permission directly from the copyright holder. To view a copy of this licence, visit http://creativecommons.org/licenses/by/4.0/.

\section{References}

Arifin, A., Parisa, A., Hazandy, A. H., Mahmud, T. M., Junejo, N., Fatemeh, A., Mohsen, S., \& Majid, N. M. (2012). Evaluation of cadmium bioaccumulation and translocation by Hopea odorata grown in a contaminated soil. African Journal of Biotechnology, 11(29), 7472-7482. https://doi. org/10.5897/AJB11.3252

Ashraf, M. A., Maah, M. J., \& Yusoff, I. (2011). Heavy metals accumulation in plants growing in ex tin mining catchment. International Journal of Environmental Science \& Technology, 8(2), 401-416. https://doi.org/10.1007/BF033 26227

Balasooriya, B. L. W. K., Samson, R., Mbikwa, F., Boeckx, P., \& Van Meirvenne, M. (2009). Biomonitoring of urban habitat quality by anatomical and chemical leaf characteristics. Environmental and Experimental Botany, 65(2-3), 386-394. https://doi.org/10.1016/j.envexpbot.2008.11.009

Bednarek, R., Dziadowiec, H., Pokojska, U., \& Prusinkiewicz, Z. (2004). Badania ekologiczno-gleboznawcze. Wydawnictwo Naukowe PWN. in Polish.

Bernardini, A., Salvatori, E., Guerrini, V., Fusaro, L., Canepari, S., \& Manes, F. (2016). Effects of high Zn and
$\mathrm{Pb}$ concentrations on Phragmites australis (Cav.) Trin. Ex. Steudel: Photosynthetic performance and metal accumulation capacity under controlled conditions. International Journal of Phytoremediation, 18(1), 16-24. https://doi. org/10.1080/15226514.2015.1058327

Bezel, V. S., Pozolotina, V. N., Bel'skii, E. A., \& Zhuikova, T. V. (2001). Variation in population parameters: Adaptation to toxic environmental factors. Russian Journal of Ecology, 32(6), 413-419. https://doi.org/10.1023/A:10125 34201258

Birouste, M., Zamora-Ledezma, E., Bossard, C., PérezRamos, I. M., \& Roumet, C. (2014). Measurement of fine root tissue density: A comparison of three methods reveals the potential of root dry matter content. Plant and Soil, 374(1-2), 299-313. https://doi.org/10.1007/ s11104-013-1874-y

Bradshaw, A. D., McNeilly, T., \& Putwain, P. D. (1989). The essential qualities. In A. J. Shaw (Ed.), Heavy metal tolerances in plants: Evolutionary aspects (pp. 323-344). CRC Press Inc.

Burt, R., Hernandez, L., Shaw, R., Tunstead, R., Ferguson, R., \& Peaslee, S. (2014). Trace element concentration and speciation in selected urban soils in New York City. Environmental Monitoring and Assessment, 186(1), 195-215. https://doi.org/10.1007/s10661-013-3366-1

Cabała, S., Orczewska, A., \& Zaufal, T. (2006). The state of preservation of the beech forest communities in the Upper Silesian Industrial Region and the perspectives for conservation. Shaping of Geographical Environment and Nature Protection in Industrialized and Urbanized Areas, 37, 5-16. in Polish.

Cabała, J., Warchulski, R., Rozmus, D., Środek, D., \& Szełęg, E. (2020). Pb-rich slags, minerals, and pollution resulted from a medieval $\mathrm{Ag}-\mathrm{Pb}$ smelting and mining operation in the Silesian-Cracovian region (southern Poland). Minerals, 10(1), 28. https://doi.org/10.1007/ s10682-004-5143-7

Cai, Q. Y., Mo, C. H., Li, H. Q., Lü, H., Zeng, Q. Y., Li, Y. W., \& Wu, X. L. (2013). Heavy metal contamination of urban soils and dusts in Guangzhou, South China. Environmental monitoring and assessment, 185(2), 10951106. https://doi.org/10.1007/s10661-012-2617-x

Černikovský, L., Krejčí, B., Blažek, Z., \& Volná, V. (2016). Transboundary air-pollution transport in the Czech-Polish border region between the cities of Ostrava and Katowice. Central European Journal of Public Health, 24, S45-S50. https://doi.org/10.21101/cejph.a4532

Chakroun, H. K., Souissi, F., Bouchardon, J. L., Souissi, R., Moutte, J., Faure, O., Remon, E., \& Abdeljaoued, S. (2010). Transfer and accumulation of lead, zinc, cadmium and copper in plants growing in abandoned mining-district area. African Journal of Environmental Science and Technology, 4(10), 651-659.

Chaves, L. H. G., Estrela, M. A., \& de Souza, R. S. (2011). Effect on plant growth and heavy metal accumulation by sunflower. Journal of Phytology, 3(12), 4-9.

Chen, T. B., Zheng, Y. M., Lei, M., Huang, Z. C., Wu, H. T., Chen, H., Yu, F.-K., Wu, X., \& Tian, Q. Z. (2005). Assessment of heavy metal pollution in surface soils of urban parks in Beijing, China. Chemosphere, 60(4), 542551. https://doi.org/10.1016/j.chemosphere.2004.12.072 
Christou, A., Theologides, C. P., Costa, C., Kalavrouziotis, I. K., \& Varnavas, S. P. (2017). Assessment of toxic heavy metals concentrations in soils and wild and cultivated plant species in Limni abandoned copper mining site, Cyprus. Journal of Geochemical Exploration, 178, 16-22. https://doi.org/10.1016/j.gexplo.2017.03.012

Čierniková, M., Vykouková, I., Orfánus, T., \& Masarovičová, E. (2021). Functional traits of plant species suitable for revegetation of landfill waste from nickel smelter. Applied Sciences, 11(2), 658. https://doi.org/10.3390/app11 020658

Cole, D. H. (1991). Cleaning up Krakow: Poland's ecological crisis and the political economy of international environmental assistance. Colorado Journal of International Environmental Law and Policy, 2, 205-245.

Czarnecka, B. (1996). Clonal organization of populations of Asarum europaeum and Maianthemum bifolium in contrasting habitats. Vegetatio, 125, 51-62. https://doi.org/10. 1007/bf00045204

Datcu, A. D., Sala, F., \& Ianovici, N. (2017). Studies regarding some morphometric and biomass allocation parameters in the urban habitat on Plantago major. Research Journal of Agricultural Science, 49(4), 96-102.

Demková, L., Jezný, T., \& Bobuská, L. (2017). Assessment of soil heavy metal pollution in a former mining area before and after the end of mining activities. Soil \& Water Research, 12, 229-236. https://doi.org/10.17221/107/ 2016-SWR

Deng, H., Ye, Z. H., \& Wong, M. H. (2004). Accumulation of lead, zinc, copper and cadmium by 12 wetland plant species thriving in metal-contaminated sites in China. Environmental Pollution, 132(1), 29-40. https://doi.org/10. 1016/j.envpol.2004.03.030

D'Hertefeld, T., \& Jonsdottir, I. S. (1994). Effects of resource availability on integration and clonal growth in Maianthemum bifolium. Folia Geobotinica Et Phytotaxonomica, 29, 167-179. https://doi.org/10.1007/BF02803793

Dinu, C., Vasile, G. G., Buleandra, M., Popa, D. E., Gheorghe, S., \& Ungureanu, E. M. (2020). Translocation and accumulation of heavy metals in Ocimum basilicum L. plants grown in a mining-contaminated soil. Journal of Soils and Sediments, 20(4), 2141-2154. https://doi.org/10.1007/ s11368-019-02550-w

Franiel, I., \& Babczyńska, A. (2011). The growth and reproductive effort of Betula pendula Roth in a heavy-metals polluted area. Polish Journal of Environmental Studies, 20(4), 1097-1101.

Haag-Kerwer, A., Schäfer, H. J., Heiss, S., Walter, C., \& Rausch, T. (1999). Cadmium exposure in Brassica juncea causes a decline in transpiration rate and leaf expansion without effect on photosynthesis. Journal of Experimental Botany, 50(341), 1827-1835. https://doi.org/10.1093/jxb/ 50.341 .1827

Hu, B., Jia, X., Hu, J., Xu, D., Xia, F., \& Li, Y. (2017). Assessment of heavy metal pollution and health risks in the soilplant-human system in the Yangtze River Delta, China. International Journal of Environmental Research and Public Health, 14(9), 1042. https://doi.org/10.3390/ijerp h14091042

Hüseyinova, R., Kutbay, H. G., Bilgin, A., Kılıç, D., Horuz, A., \& Kırmanoğlu, C. (2009). Sulphur and some heavy metal contents in foliage of Corylus avellana and some roadside native plants in Ordu Province, Turkey. Ekoloji, 18(70), 10-16.

Islam, E., Yang, X., Li, T., Liu, D., Jin, X., \& Meng, F. (2007). Effect of $\mathrm{Pb}$ toxicity on root morphology, physiology and ultrastructure in the two ecotypes of Elsholtzia argyi. Journal of Hazardous Materials, 147(3), 806-816. https:// doi.org/10.1016/j.jhazmat.2007.01.117

Jamnická, G., Bučinová, K., Havranová, I., \& Urban, A. (2007). Current state of mineral nutrition and risk elements in a beech ecosystem situated near the aluminium smelter in Žiar nad Hronom, Central Slovakia. Forest Ecology and Management, 248(1-2), 26-35. https://doi.org/10.1016/j. foreco.2007.02.033

Jamnická, G., Válka, J., \& Bublinec, E. (2013). Heavy metal accumulation and distribution in forest understory herb species of Carpathian beech ecosystems. Chemical Speciation \& Bioavailability, 25(3), 209-215. https://doi.org/ 10.3184/095422913X13785568683285

Jiménez-Ambriz, G., Petit, C., Bourrié, I., Dubois, S., Olivieri, I., \& Ronce, O. (2007). Life history variation in the heavy metal tolerant plant Thlaspi caerulescens growing in a network of contaminated and noncontaminated sites in southern France: Role of gene flow, selection and phenotypic plasticity. New Phytologist, 173(1), 199-215. https:// doi.org/10.1111/j.1469-8137.2006.01923.x

Kabata-Pendias, A., \& Pendias, H. (1999). Biogeochemia pierwiastków śladowych. PWN. in Polish.

Kardel, F., Wuyts, K., Babanezhad, M., Wuytack, T., Potters, G., \& Samson, R. (2010). Assessing urban habitat quality based on specific leaf area and stomatal characteristics of Plantago lanceolata L. Environmental Pollution, 158(3), 788-794. https://doi.org/10.1016/j.envpol.2009.10.006

Kaur, G., Singh, H. P., Batish, D. R., \& Kohli, R. K. (2014). $\mathrm{Pb}$-inhibited mitotic activity in onion roots involves DNA damage and disruption of oxidative metabolism. Ecotoxicology, 23(7), 1292-1304. https://doi.org/10.1007/ s10646-014-1272-0

Kim, S. C., \& Lee, N. S. (2007). Generic delimitation and biogeography of Maianthemum and Smilacina (Ruscaceae sensu lato): Preliminary results based on partial $3^{\prime}$ matK gene and trnK $3^{\prime}$ intron sequences of cpDNA. Plant Systematics and Evolution, 265(1-2), 1-12.

Kim, R. Y., Yoon, J. K., Kim, T. S., Yang, J. E., Owens, G., \& Kim, K. R. (2015). Bioavailability of heavy metals in soils: Definitions and practical implementation-a critical review. Environmental Geochemistry and Health, 37(6), 1041-1061. https://doi.org/10.1007/s10653-015-9695-y

Klink, A., Macioł, A., Wisłocka, M., \& Krawczyk, J. (2013). Metal accumulation and distribution in the organs of Typha latifolia L. (cattail) and their potential use in bioindication. Limnologica, 43(3), 164-168. https://doi.org/10. 1016/j.limno.2012.08.012

Koivunen, S., Saikkonen, K., Vuorisalo, T., \& Mutikainen, P. (2004). Heavy metals modify costs of reproduction and clonal growth in the stoloniferous herb Potentilla anserina. Evolutionary Ecology, 18(5-6), 541-561. https://doi. org/10.1007/s10682-004-5143-7

Kondracki, J. (2002). Regional geography of Poland. PWN. in Polish. 
Kozanecka, T., Chojnicki, J., \& Kwasowski, W. (2002). Content of heavy metals in plant from pollution-free regions. Polish Journal of Environmental Studies, 11(4), 395-400.

Łaszewska, A., Kowol, J., Wiechuła, D., \& Kwapuliński, J. (2007). Kumulacja metali w wybranych gatunkach roślin leczniczych z terenu Beskidu Śląskiego i Żywieckiego. Problemy Ekologii, 11, 285-291. in Polish.

Lavorel, S., \& Garnier, E. (2002). Predicting changes in community composition and ecosystem functioning from plant traits: Revisiting the holy grail. Functional Ecology, 16(5), 545-556. https://doi.org/10.1046/j.1365-2435. 2002.00664.x

Lis, J., \& Pasieczna, A. (1997). Anomalie geochoemiczne PbZn-Cd w glebach na Górnym Śląsku. Przeglad Geologiczny, 45(2), 182-189. in Polish.

Loska, K., Wiechuła, D., \& Korus, I. (2004). Metal contamination of farming soils affected by industry. Environment International, 30(2), 159-165. https://doi.org/10. 1016/S0160-4120(03)00157-0

Luwe, M. W. (1995). Distribution of nutrients and phytotoxic metal ions in the soil and in two forest floor plant species of a beech (Fagus sylvatica L.) stand. Plant and soil, 168(1), 195-202. https://doi.org/10.1007/BF000 29329

Madejón, P., Murillo, J. M., Marañón, T., Cabrera, F., \& Soriano, M. A. (2003). Trace element and nutrient accumulation in sunflower plants two years after the Aznalcóllar mine spill. Science of the Total Environment, 307(1-3), 239-257. https://doi.org/10.1016/S00489697(02)00609-5

Magiera, T., Strzyszcz, Z., \& Rachwal, M. (2007). Mapping particulate pollution loads using soil magnetometry in urban forests in the Upper Silesia Industrial Region, Poland. Forest Ecology and Management, 248(1), 36-42. https://doi.org/10.1016/j.foreco.2007.02.034

Mehes-Smith, M., Nkongolo, K., \& Cholewa, E. (2013). Coping mechanisms of plants to metal contaminated soil. Environmental Change and Sustainability, 54, 53-90. https://doi.org/10.5772/55124

Molenda, T. (2013). The protection of anthropogenic habitats in Poland. Journal of Ecology and Health, 17(2), 76-80.

Mukherjee, A. B., \& Nuorteva, P. (1994). Toxic metals in forest biota around the steel works of Rautaruukki Oy, Raahe, Finland. Science of the Total Environment, 151(3), 191-204. https://doi.org/10.1016/0048-9697(94)90468-5

Oborny, B. (1994). Spacer length in clonal plants and the efficiency of resource capture in heterogeneous environments: A Monte Carlo simulation. Folia Geobotanica, 29(2), 139-158. https://doi.org/10.1007/BF02803791

Ociepa-Kubcka, A., \& Ociepa, E. (2012). Toksyczne oddziaływanie metali ciężkich na rośliny, zwierzęta i ludzi. Inżynieria i Ochrona Środowiska, 15, 169-180.

Oliva, S. R., \& Espinosa, A. F. (2007). Monitoring of heavy metals in topsoils, atmospheric particles and plant leaves to identify possible contamination sources. Microchemical Journal, 86(1), 131-139. https://doi.org/10.1016/j.microc. 2007.01.003

Ortiz, A., \& Guerreiro, C. (2020). Air quality in Europe - 2020 report. . https://doi.org/10.2800/786656

Ouzounidou, G., Čiamporová, M., Moustakas, M., \& Karataglis, S. (1995). Responses of maize (Zea mays L.) plants to copper stress-I. growth, mineral content and ultrastructure of roots. Environmental and experimental botany, 35(2), 167-176. https://doi.org/10.1016/0098-8472(94) 00049-B

Panda, P., Nath, S., Chanu, T. T., Sharma, G. D., \& Panda, S. K. (2011). Cadmium stress-induced oxidative stress and role of nitric oxide in rice (Oryza sativa L.). Acta Physiologiae Plantarum, 33, 1737-1747. https://doi.org/10. 1007/s11738-011-0710-3

Papazoglou, E. G., Karantounias, G. A., Vemmos, S. N., \& Bouranis, D. L. (2005). Photosynthesis and growth responses of giant reed (Arundo donax L.) to the heavy metals Cd and Ni. Environment International, 31(2), 243249. https://doi.org/10.1016/j.envint.2004.09.022

Parusel, J. B. (2011). Zbiorowiska leśne i ich zagrożenia w województwie śląskim. Przyroda Górnego Ślaska, 66, 3-4. in Polish.

Pasieczna, A., Dusza-Dobek, A., \& Kowalska, Z. (2010). Detailed geochemical map of Upper Silesa 1:25000.

Pérez-Harguindeguy, N., Díaz, S., Garnier, E., Lavorel, S., Poorter, H., Jaureguiberry, P., Bret-Harte, M. S., Cornwell, W. K., Craine, J. M., Gurvich, D. E., Urcelay, C., Veneklaas, E. J., Reich, P. B., Poorter, L., Wright, I. J., Ray, P., Enrico, L., Pausas, J. G., de Vos, A. C., ... \& Cornelissen, J. H. C. (2013). New handbook for standardised measurement of plant functional traits worldwide. Australian Journal of Botany, 61, 167-234.

Polechoński, R., Dobicki, R., Drabiński, A., \& AdynkiewiczPiragas, M. (2018). In M. Kowalska-Góralska (Ed.), Aspekty ekonomiczne, ekologiczne i prawne $w$ akwakulturze karpia. (pp. 233-261). Polskie Towarzystwo Rybackie (in Polish)

Rezvani, M., \& Zaefarian, F. (2011). Bioaccumulation and translocation factors of cadmium and lead in Aeluropus littoralis. Australian Journal of Agricultural Engineering, 2(4), 114-119. https://doi.org/10.3316/informit.68384 3973571084

Rutherford, P., McGill, W. B., Arocena, J., \& Figueiredo, C. (2007). Soil sampling and methods of analysis. In M. R. Carter \& E. G. Gregorich (Eds.), Soil sampling and methods of analysis (pp. 267-278). CRC Press. https://doi.org/ 10.1201/9781420005271

Ryser, P., \& Sauder, W. R. (2006). Effects of heavy-metal-contaminated soil on growth, phenology and biomass turnover of Hieracium piloselloides. Environmental Pollution, 140(1), 52-61. https://doi.org/10.1016/j.envpol.2005.06. 026

Salehi, M. H., Beni, O. H., Harchegani, H. B., Borujeni, I. E., \& Motaghian, H. R. (2011). Refining soil organic matter determination by loss-on-ignition. Pedosphere, 21, 473482. https://doi.org/10.1016/S1002-0160(11)60149-5

Sastre, J., Sahuquill, A., Vidal, M., \& Rauret, G. (2002). Determination of $\mathrm{Cd}, \mathrm{Cu}, \mathrm{Pb}$ and $\mathrm{Zn}$ in environmental samples: Microwave-assisted total digestion versus aqua regia and nitric acid extraction. Analytica Chimica Acta, 462(1), 59-72. https://doi.org/10.1016/S0003-2670(02)00307-0

Sert, E. B., Turkmen, M., \& Cetin, M. (2019). Heavy metal accumulation in rosemary leaves and stems exposed to traffic-related pollution near Adana-İskenderun Highway (Hatay, Turkey). Environmental Monitoring and 
Assessment, 191(9), 1-12. https://doi.org/10.1007/ s10661-019-7714-7

Shahid, M., Dumat, C., Khalid, S., Niazi, N. K., \& Antunes, P. M. C. (2016). Cadmium bioavailability, uptake, toxicity and detoxification in soil-plant system. In F. A. Gunther \& P. de Voogt (Eds.), Reviews of environmental contamination and toxicology (Vol. 241, pp. 73-137). Springer. https://doi.org/10.1007/398_2016_8

Shovon, T. A., Rozendaal, D. M., Gagnon, D., Gendron, F., Vetter, M., \& Vanderwel, M. C. (2020). Plant communities on nitrogen-rich soil are less sensitive to soil moisture than plant communities on nitrogen-poor soil. Journal of Ecology, 108(1), 133-144. https://doi.org/10.1111/13652745.13251

Siddiqui, S. (2015). DNA damage in Cicer plant grown on soil polluted with heavy metals. Journal of King Saud University-Science, 27(3), 217-223. https://doi.org/10.1016/j. jksus.2015.02.004

Singh, G., \& Bhati, M. (2003). Mineral toxicity and physiological functions in tree seedlings irrigated with effluents of varying chemistry in sandy soil of dry region. Journal of Environmental Science and Health, Part C, 21(1), 45-63. https:// doi.org/10.1081/GNC-120021373

Skálová, H., Pecháčková, S., Suzuki, J., Herben, T., Hara, T., Hadincová, V., \& Krahulec, F. (1997). Within population genetic differentiation in traits affecting clonal growth: Festuca rubra in a mountain grassland. Journal of Evolutionary Biology, 10(3), 383-406. https://doi.org/10.1046/j.1420-9101.1997.10030383.x

Stefanowicz, A. M., Woch, M. W., \& Kapusta, P. (2014). Inconspicuous waste heaps left by historical $\mathrm{Zn}-\mathrm{Pb}$ mining are hot spots of soil contamination. Geoderma, 235, 1-8. https://doi.org/10.1016/j.geoderma.2014.06.020

Stefanowicz, A., Stanek, M., \& Woch, M. (2016). High concentrations of heavy metals in beech forest understory plants growing on waste heaps left by $\mathrm{Zn}-\mathrm{Pb}$ ore mining. Journal of Geochemical Exploration, 106, 157-162. https://doi.org/ 10.1016/j.gexplo.2016.07.026

Ter Braak, C. J., \& Smilauer, P. (2002). CANOCO reference manual and CanoDraw for Windows user's guide: Software for canonical community ordination (version 4.5).

Todeschini, V., Lingua, G., D'agostino, G., Carniato, F., Roccotiello, E., \& Berta, G. (2011). Effects of high zinc concentration on poplar leaves: A morphological and biochemical study. Environmental and Experimental Botany, 71(1), 50-56. https://doi.org/10.1016/j.envexpbot.2010.10.018

Ullrich, S. M., Ramsey, M. H., \& Helios-Rybicka, E. (1999). Total and exchangeable concentrations of heavy metals in soils near Bytom, an area of $\mathrm{Pb} / \mathrm{Zn}$ mining and smelting in Upper Silesia, Poland. Applied Geochemistry, 14(2), 187196. https://doi.org/10.1016/S0883-2927(98)00042-0

Vesley, T., Neuberg, M., Trakal, L., Szkova, J., \& Tlustoa, P. (2012). Water lettuce Pistia stratiotes L. response to lead toxicity. Water Air \& Soil Pollution, 223(4), 1847-1859. https://doi.org/10.1007/s11270-011-0989-0

Violle, C., Navas, M. L., Vile, D., Kazakou, E., Fortunel, C., Hummel, I., \& Garnier, E. (2007). Let the concept of trait be functional! Oikos, 116(5), 882-892. https://doi.org/10. 1111/j.0030-1299.2007.15559.x

Wang, Y., Duan, X., \& Wang, L. (2020). Spatial distribution and source analysis of heavy metals in soils influenced by industrial enterprise distribution: Case study in Jiangsu province.
Science of the Total Environment, 710, 134953. https://doi. org/10.1016/j.scitotenv.2019.134953

Wang, Y., Xiong, Y., Wang, Y., \& Li, Q. (2021). Long period exposure to serious cadmium pollution benefits an invasive plant (Alternanthera philoxeroides) competing with its native congener (Alternanthera sessilis). Science of the Total Environment, 786, 147456. https://doi.org/10.1016/j.scito tenv.2021.147456

Westoby, M. (1998). A leaf-height-seed (LHS) plant ecology strategy scheme. Plant and Soil, 199(2), 213-227. https:// doi.org/10.1023/A:1004327224729

Woch, M. W., Stefanowicz, A. M., \& Stanek, M. (2017). Waste heaps left by historical $\mathrm{Zn}-\mathrm{Pb}$ ore mining are hotspots of species diversity of beech forest understory vegetation. Science of the Total Environment, 599, 32-41. https://doi.org/ 10.1016/j.scitotenv.2017.04.197

Wójcik, M., \& Tukiendorf, A. (2005). Cadmium uptake, localization and detoxification in Zea mays. Biologia Plantarum, 49(2), 237-245.

Wójcik, M., Dresler, S., Jawor, E., Kowalczyk, K., \& Tukiendorf, A. (2013). Morphological, physiological, and genetic variation between metallicolous and nonmetallicolous populations of Dianthus carthusianorum. Chemosphere, 90(3), 1249-1257. https://doi.org/10.1016/j.chemosphere.2012.09. 068

Wójcik, M., Sugier, P., \& Siebielec, G. (2014). Metal accumulation strategies in plants spontaneously inhabiting $\mathrm{Zn}-\mathrm{Pb}$ waste deposits. Science of The Total Environment, 487, 313322. https://doi.org/10.1016/j.scitotenv.2014.04.024

Woś, A. (2010). Polish climate in the second half of the XX century. Adam Mickiewicz University Scientific Publishing. in Polish.

Yang, Q., Li, Z., Lu, X., Duan, Q., Huang, L., \& Bi, J. (2018). A review of soil heavy metal pollution from industrial and agricultural regions in China: Pollution and risk assessment. Science of the Total Environment, 642, 690-700. https://doi. org/10.1016/j.scitotenv.2018.06.068

Yoon, J., Cao, X., Zhou, Q., \& Ma, L. Q. (2006). Accumulation of $\mathrm{Pb}, \mathrm{Cu}$, and $\mathrm{Zn}$ in native plants growing on a contaminated Florida site. Science of the Total Environment, 368(23), 456-464. https://doi.org/10.1016/j.scitotenv.2006.01.016

Yruela, I. (2005). Copper in plants. Brazilian Journal of Plant Physiology, 17, 145-156. https://doi.org/10.1590/S167704202005000100012

Yuanan, H., He, K., Sun, Z., Chen, G., \& Cheng, H. (2020). Quantitative source apportionment of heavy metal (loid) $s$ in the agricultural soils of an industrializing region and associated model uncertainty. Journal of Hazardous Materials, 391, 122244. https://doi.org/10.1016/j.jhazmat.2020.122244

Zhang, N., Zhang, J. W., Yang, Y. H., Li, X. Y., Lin, J. X., Li, Z. L., Cheng, L. Y., Wang, J. F., Mu, C. S., \& Wang, A. X. (2015). Effects of lead contamination on the clonal propagative ability of Phragmites australis (common reed) grown in wet and dry environments. Plant Biology, 17(4), 893-903. https://doi.org/10.1111/plb.12317

Zhao, H., \& Li, X. (2013). Risk assessment of metals in roaddeposited sediment along an urban-rural gradient. Environmental Pollution, 174, 297-304. https://doi.org/10.1016/j. envpol.2012.12.009

Zhao, L., Xu, Y., Hou, H., Shangguan, Y., \& Li, F. (2014). Source identification and health risk assessment of metals in urban 
soils around the Tanggu chemical industrial district, Tianjin, China. Science of the Total Environment, 468, 654-662. https://doi.org/10.1016/j.scitotenv.2013.08.094

Zvereva, E. L., Roitto, M., \& Kozlov, M. V. (2010). Growth and reproduction of vascular plants in polluted environments: A synthesis of existing knowledge. Environmental Reviews, 18, 355-367. https://doi.org/10.1139/A10-017
Publisher's Note Springer Nature remains neutral with regard to jurisdictional claims in published maps and institutional affiliations. 